NBER WORKING PAPER SERIES

\title{
DIRECT AND INDIRECT EFFECTS OF TEENAGE BODY WEIGHT ON ADULT WAGES
}

\author{
Euna Han \\ Edward C. Norton \\ Lisa M. Powell \\ Working Paper 15027 \\ http://www.nber.org/papers/w15027
}

\author{
NATIONAL BUREAU OF ECONOMIC RESEARCH \\ 1050 Massachusetts Avenue \\ Cambridge, MA 02138 \\ June 2009
}

The views expressed herein are those of the author(s) and do not necessarily reflect the views of the National Bureau of Economic Research.

NBER working papers are circulated for discussion and comment purposes. They have not been peerreviewed or been subject to the review by the NBER Board of Directors that accompanies official NBER publications.

(C) 2009 by Euna Han, Edward C. Norton, and Lisa M. Powell. All rights reserved. Short sections of text, not to exceed two paragraphs, may be quoted without explicit permission provided that full credit, including $(\odot$ notice, is given to the source. 
Direct and Indirect Effects of Teenage Body Weight on Adult Wages

Euna Han, Edward C. Norton, and Lisa M. Powell

NBER Working Paper No. 15027

June 2009

JEL No. I1,J31

\begin{abstract}
$\underline{\text { ABSTRACT }}$
Previous estimates on the association between body weight and wages in the literature have been contingent on education and occupation. This paper examines the direct effect of BMI on wages and the indirect effects operating through education and occupation choice, particularly for late-teen BMI and adult wages. Using the National Longitudinal Survey of Youth 1979 data, we show that education is the main pathway for the indirect BMI wage penalty. The total BMI wage penalty is underestimated by $18 \%$ for women without including those indirect effects. Whereas for men there is no statistically significant direct BMI wage penalty, we do observe a small indirect wage penalty through education.
\end{abstract}

Euna Han

Institute for Health Research

and Policy (MC 275)

University of Illinois at Chicago

1747 West Roosvelt Road, Room 449

Chicago, Illinois 60608

eunahan@uic.edu

\author{
Lisa M. Powell \\ Institute for Health Research and Policy \\ University of Illinois at Chicago \\ 1747 W. Roosevelt Road \\ Rm 558, MC275 \\ Chicago, IL 60608 \\ powelll@uic.edu
}

\author{
Edward C. Norton \\ Department of Health Management and Policy \\ Department of Economics \\ University of Michigan \\ School of Public Health \\ 109 S. Observatory Drive, M3108 SPH II \\ Ann Arbor, MI 48109-2029 \\ and NBER \\ ecnorton@umich.edu
}




\section{INTRODUCTION}

Over the past few decades, the prevalence of obesity has risen dramatically in the United States. One-third of American adults were reported to be obese in 2003-2004 (Odgen et al., 2006). Given these trends, there is great interest in the economic consequences of obesity. Many economic studies have recently reported finding a negative effect of body mass index (BMI) or obesity on labor market outcomes, such as hourly wages, particularly for women (Averett and Korenman, 1996; Pagan and Davila, 1997; Cawley, 2004; Baum and Ford, 2004; Conley and Glauber, 2005; Norton and Han, 2008; Han, Norton, and Stearns, 2009) and the probability of employment (Sarlio-Lahteenkorva and Lahelma 1999; Cawley 2000; Paraponaris, Saliba, and Ventelou, 2005; Tunceli and Williams 2006; Garcia and Quintana-Domeque 2007; Lundborg et al. 2007; Morris 2007; Norton and Han, 2008; Han, Norton, and Stearns, 2009).

Economists are especially interested in understanding why BMI or obesity may affect labor market outcomes. Most explanations are conditional on having a job, and may explain either differences in initial wages or in wage growth. In this study, we provide empirical evidence on the BMI wage penalty stemming from two indirect pathways - education and occupation choices - compared to the direct effect which conditions on education and occupation.

In particular, we focus on the effect of BMI in the late teenage years (late teen BMI) on future wages in the early thirties (adult wages). Many important decisions that affect future employment and wages are made during the late teens. These decisions include education and job sector choices (Norton and Han, 2008). By examining the relationship between BMI in the early part of the life-cycle (i.e., the late teenage years) and future education and employment and occupation outcomes in the early thirties, we are able to identify whether different levels in the stock of education or sorting into different occupations is a potential path that explains the BMI 
wage penalty. That is, the wage penalty for obese individuals or people with higher BMI may not be fully caused by employers' or customers' distaste for contemporaneously overweight or obese adults or lower productivity, but additionally may be related to characteristics (here, the stock of education or occupation choices) associated with BMI in the late teenage years. Therefore, we distinguish the effect of late teen BMI from the effect of contemporaneous BMI in the early thirties, by which time people have usually accumulated their full stock of education.

Our study contributes to the previous literature by empirically testing whether individuals make choices for their career paths based on their BMI status prior to job search. We examine the extent to which individuals with different late teen BMI have different labor market outcomes, particularly, hourly wages, in their early thirties, and whether such differences may be attributable to education and occupation choice among service, sales, managerial or professional specialty, administrative support or clerical, or blue-collar jobs. This helps to understand how late teen BMI may affect adult labor market outcomes, either directly (conditional on education and occupation) or indirectly through education and occupation choices. Further, we quantify the relative contributions of these indirect factors on the wage penalty for increasing BMI.

We also build on a hypothesis from the psychology literature about the importance of social interactions (Frieze et al. 1990; Martel and Biller 1987). The lack of accumulation of some forms of human capital— such as interpersonal skills or perseverance — may be due to stigma or lack of self-image during the teenage years. We control for whether an occupation requires social interactions using the Dictionary of Occupational Titles in addition to Census occupation codes. The aggregate Census occupational codes generate occupation categories based on overall characteristics of each occupation (Pagan and Davilla 1997; Baum and Ford 2004). Given that occupations in the same Census classification can have different requirements for social 
interaction with customers or colleagues, this additional control may partly explain the BMI wage penalty.

Our results suggest that higher BMI for both women and men in their late teenage years decreases the stock of education acquired by the early thirties which affects wages and the lower stock of education affects occupation choice which also affects wages. We find that late teen BMI does not generally affect occupation choice in the early thirties with the exception among women of reducing the likelihood of being in blue-collar occupations and occupations requiring social interactions.

Finally, we show that previous studies on the BMI wage penalty for women that condition on employment and occupation choice underestimate the total effect by $19 \%$ given that we estimate a 0.18 percent indirect reduction $(90 \% \mathrm{CI}$ : $[0.032,0.32])$ in wages in addition to a 0.78 percent $(90 \%$ CI: $[0.18,1.38])$ direct BMI wage penalty from a one-unit increase in late teen BMI. For men, no observed direct BMI wage penalty is found. Also for men, whereas we do find a statistically significant indirect effect of teen BMI on wages through education and through education on occupation choice, the total indirect effect does not achieve statistical significance.

\section{PREVIOUS LITERATURE}

Several studies have linked BMI or obesity to labor market outcomes, mostly wages. Most of those studies find a negative contemporaneous effect of BMI or obesity on hourly wages for women, but no significant effect for men (Cawley 2004; Averett and Korenman 1996; Conley and Glauber 2005; Baum and Ford 2004; and Han, Norton, and Stearns 2009). For women, the wage penalty for a unit increase in BMI is found not only for their own earnings and occupational prestige measured by Duncan's Socioeconomics Index, but also their spouses' 
earnings and occupational prestige as in Conley and Glauber (2005). The direction and the magnitude of the effects are different by race within each gender, and one study by Cawley (2004) finds obesity penalties for wages for only white women. Also, the often-reported negative relationship between the BMI and wages is larger in occupations requiring interpersonal skills with presumably more social interactions as in Han, Norton, and Stearns (2009).

We have found only a handful of studies investigating the effect of BMI or obesity on the extensive margin of the labor market, such as employment or occupation choice. For example, Morris (2007) estimates a negative relationship between obesity and the probability of employment for British people for both genders. Morris also highlights the importance of separately identifying being out of the labor force from unemployment, so we also do this. Paraponaris and colleagues (2005) report that a one standard deviation increase of BMI from the mean at age 20 raises the percentage of time spent unemployed during the working years and lowers the probability of employment after a period of unemployment for both men and women. Cawley (2000) indicates no statistically significant effect of obesity on limitations on the amount of paid work, types of paid work, or probability of employment. Pagan and Davila (1997)'s study reports that both obese men and women are less likely to sort into managerial, professional and technical occupations among fourteen Census occupation categories.

A few papers seek to disentangle the supply side from the consumer side effect in the association of obesity on labor market penalties at the extensive margin. Harper (2000) shows a positive effect of being physically attractive on the probability of employment for women, particularly on the probability of working in managerial or professional specialty and clerical occupations. However, the study finds neither occupational sorting into customer-oriented occupations caused by physical attractiveness nor a wage penalty for non-attractive women 
working in customer-oriented jobs. Carpenter (2006) compares the employment rate for obese people to normal-weight people before (1988) and after (1999) a 1993 court case, Cook vs. Rhode Island. In that case, obesity is ruled to be covered under the Rehabilitation Act of 1973 and the Americans with Disabilities Act for the first time by a federal appeals court. The data show that the employment rate increased $4 \%$ for obese women and $2 \%$ for obese men compared to their respective non-obese counterparts after the court case, but no effect for overweight men and morbidly obese women.

We found only one paper estimating the effect of obesity on educational achievements. A study by Sabia (2007) reports that white women have a GPA penalty for being obese, whereas non-white women and men do not. The author uses parent-reported self-classification for obesity as an IV for adolescent BMI. The study results suggest that the often-reported wage penalty for obesity may partially be due to low human capital. However, if parents' self-classification for obesity reflects the level of their self-esteem or time preference, it should not be excluded from their children's educational achievement, and therefore, would not serve as a good instrument.

\section{MECHANISMS FOR THE BMI WAGE PENALTY}

The direct BMI wage penalty may operate primarily through discrimination by employers who want to avoid obese employees who may have lower productivity or higher health care costs as suggested by Baum and Ford (2004) and Bhattacharya and Bundorf (2005). Concerns about customers' distaste for overweight or obese employees — particularly in sales industries — may also make employers shun overweight or obese employees. Although we do not test these direct pathways for the BMI or obesity wage penalty in this study, these mechanisms have been supported in some of the previous literature. For example, Everett (1990) and Puhl and Brownell 
(2001) demonstrated that employers perceived obese persons as unfit for public sales positions and as more appropriate for telephone sales involving little face-to-face contact.

The overall BMI wage gap also may indirectly stem in part from choices made prior to being hired into a particular job. If the extent of BMI or obesity is an observed trait of less investment in future health due to a high discount rate, then overweight or obese teenagers may also be less likely to invest in their human capital, and accordingly achieve a lower stock of education by the time they participate in the labor market in their adult years. The extent of the wage penalty for high BMI would then be expected to decrease once the relationship is estimated contingent on the stock of education.

Regardless of time preferences, individuals may choose their career paths to optimize their labor market outcomes in their initial job search. For example, a person who enjoys conversation may consider a sales job rather than working alone as a computer programmer. Similarly, overweight or obese individuals may sort into occupations in which their body weight status does not lower their marginal productivity. A teenager may take a signal from the market that their BMI status could be detrimental in their marginal productivity in some jobs such as sales, managerial or professional jobs, or occupations requiring social interactions with customers or colleagues. The optimal choice in this case would be to choose a career path that minimizes such potential adverse outcomes. Again, the estimated extent of the wage penalty would then be expected to diminish once the association is estimated conditional on occupation.

Further, teenagers with high BMI, regardless of the reasons for the high BMI, may encounter stigma with regard to their stature and poor self-esteem, which affects the accumulation of interpersonal skills or perseverance for social interactions. The lack of such human capital formation may hinder their performance in their jobs, and contribute to the BMI 
wage penalty. However, testing this indirect channel is challenging because the empirical work needs to distinguish the lack of interpersonal skills from the individuals' purposeful choice of occupation given their interpersonal skills.

Finally, a form of statistical discrimination may underlie the indirect BMI wage penalty. If overweight or obese teenagers presciently observe smaller returns to human capital for overweight or obese people, then they may logically invest less in their human capital (see Persico, Postlewaite, and Silverman (2004) for an explanation applied to height). This mechanism, based on statistical discrimination, may be empirically tested, for example, by regressing wage on the years of schooling and its interaction with BMI or an obesity indicator.

\section{EMPIRICAL MODELS}

The objective of the empirical work is to provide evidence on the extent of the effects of BMI in the late teenage years between age 16 and 20 on long-term wages in the early thirties directly and indirectly through education and occupation choice.

Following established conceptual frameworks that include BMI as a predictor of wages as in Cawley (2004) and Han, Norton, and Stearns (2009), we present an empirical model that predicts wages as a function of BMI (the direct effect), education and occupation choice (indirect effects of BMI), and other factors. Following the labor literature, we take the logarithm of wages and estimate separate models for men and women. The main model is

$$
\begin{aligned}
& \ln \left(\text { Wage }_{i 2}\right)=\gamma^{0}+\gamma^{B M I} B M I_{i 1}+\gamma^{\Delta B M I}\left(B M I_{i 2}-B M I_{i 1}\right)+\gamma^{E d u c} E d u c_{i 2}\left(B M I_{i 1}\right) \\
& +\gamma^{\text {Occ_Census }} \operatorname{OccCens}_{i 2}\left(B M I_{i 1}, B M I_{i 2}-B M I_{i 1}, E_{d u c_{i 2}}\left(B M I_{i 1}\right)\right) \\
& +\gamma^{O c c_{-} S I} \operatorname{OccSI}_{i 2}\left(B M I_{i 1}, B M I_{i 2}-B M I_{i 1}, E d u c_{i 2}\left(B M I_{i 1}\right)\right)+\gamma^{X} X_{i 2}+\varepsilon_{i 2}
\end{aligned}
$$

where the subscripts $i, 1$, and 2 stand for individual, time 1 at the late teenage years between age 16 and 20, and time 2 in the early thirties (hereafter also referred to as early career), 
respectively. The $\gamma$ 's are parameters to be estimated, and $\varepsilon$ denotes the error term. Educ is a continuous variable measuring the highest grade completed. OccCens is a vector of dummy variables measuring occupation choice among service, sales, managerial or professional specialty, administrative support or clerical jobs, with blue-collar jobs as the reference category based on aggregate Census occupational codes. OccSI is a dichotomous indicator for jobs requiring social interactions with colleagues or customers based on the Dictionary of Occupational Titles. Other covariates known to affect wages, such as demographics and the regional unemployment rate, are denoted by $X$.

We include the change in BMI (the third term in equation (1) above) in our specification to control for an omitted variable bias caused from a correlation of employment or occupation with contemporaneous BMI that is correlated with lagged BMI. We, however, are not interpreting the estimate for the change in BMI $\left(\gamma^{\triangle B M I}\right)$ given that it is not the main regressor.

The effect of a unit change in late teen BMI on the logarithm of wages in the early career stage is the full derivative of the logarithm of wages in the early career with respect to late teen BMI, taking into account the indirect effect of late teen BMI through education and occupation choice in the early career. The full derivative is

$$
\begin{aligned}
\frac{d \ln \left(\text { Wage }_{2}\right.}{d B M I_{1}} & =\frac{\partial \ln (\text { Wage })_{2}}{\partial B M I_{1}}+\left(\frac{\partial \ln (\text { Wage })_{2}}{\partial E d u c_{2}} \times \frac{\partial E d u c_{2}}{\partial B M I_{1}}\right) \\
& +\left(\frac{\partial \ln \left(\text { Wage }_{2}\right.}{\partial \text { Occ Cens }_{2}} \times \frac{\partial \text { OccCens }_{2}}{\partial B M I_{1}}\right)+\left(\frac{\partial \ln \left(\text { Wage }_{2}\right.}{\partial \text { OccSI }_{2}} \times \frac{\partial \mathrm{OccSI}_{2}}{\partial B M I_{1}}\right) \\
& +\left(\frac{\partial \ln \left(\text { Wage }_{2}\right.}{\partial \text { OccCens }_{2}} \times \frac{\partial \text { OccCens }_{2}}{\partial E d u c_{2}} \times \frac{\partial E d u c_{2}}{\partial B M I_{1}}\right)+\left(\frac{\partial \ln \left(\text { Wage }_{2}\right.}{\partial \text { OccSI }_{2}} \times \frac{\partial \text { OcCSI }_{2}}{\partial E d u c_{2}} \times \frac{\partial E d u c_{2}}{\partial B M I_{1}}\right)
\end{aligned}
$$

The first term on the right hand side is what the prior literature conventionally estimates as the direct effect of BMI on log wages controlling for both education and occupation choice. The next term estimates the indirect effect of BMI on log wages that operates through education. The 
third and fourth terms are the indirect BMI wage penalties through occupation choice, measured as the Census occupational categories (the third term) and the occupational characteristics of requiring social interactions with customers or colleagues (the fourth term). The last two terms account for the effect of BMI on wages through education on occupation choice. Although equation (2) shows derivatives, we actually compute incremental effects when the variables are not continuous. We directly obtain marginal effects from the parameter estimates for linear models (wage and education equations), but the marginal effects are calculated and the corresponding standard errors are bootstrapped for nonlinear discrete choice models (occupation choice). Equation (2) shows that reporting the BMI wage penalty based on only the first term of Equation (2) would underestimate the magnitude of the total effect, if BMI decreases education attainment and promotes selecting lower-paying occupations, and higher stock of education and certain occupations have a positive effect on wages. We calculate the extent of the underreported indirect effects out of the total effect (i.e., (5 indirect effects)/(total effect)).

Only the first term of the partial derivatives in equation (2) can be estimated from equation (1). To calculate the other terms, we estimate models to predict education and occupation choice. We begin by assessing the effect of late teen BMI on the stock of education accumulated by the time an individual reaches their early 30 s using OLS. We specify education as the years of schooling completed by the early thirties as a function of late teen BMI and other factors in the early thirties.

$$
E d u c_{i 2}=\alpha^{0}+\alpha^{B M I} B M I_{i 1}+\alpha^{X} X_{i 2}+\eta_{i 2}
$$

where the $\alpha$ 's are the parameters to be estimated, $\eta$ denotes the error term, and other variables are defined as before. If individuals with higher late teen BMI have higher discount rates, they are likely to accumulate a lower stock of education. Alternatively, teenagers may invest less in 
their education rationally if they observe lower return on education for people with higher BMI. Both scenarios suggest that $\alpha^{B M I}$ is negative.

Next, we estimate reduced form multinomial logit models of the effect of late teen BMI on occupation choice in the early career based on the Census occupational codes (equation (4)) and the Dictionary of Occupational Titles for the requirement of social interaction (equation (5)).,

$$
\begin{aligned}
& \text { OccCens }_{i 2}=\delta^{0}+\delta^{B M I} B M I_{i 1}+\delta^{E d u c} E d u c_{i 2}\left(B M I_{i 1}\right)+\delta^{\Delta}\left(B M I_{i 2}-B M I_{i 1}\right)+\delta^{X} X_{i 2}+v_{i 2} \\
& \operatorname{OccSI}_{i 2}=\beta^{0}+\beta^{B M I} B M I_{i 1}+\beta^{E d u c} E d u c_{i 2}\left(B M I_{i 1}\right)+\beta^{\Delta}\left(B M I_{i 2}-B M I_{i 1}\right)+\beta^{X} X_{i 2}+\varsigma_{i 2}
\end{aligned}
$$

where the $\delta$ 's and $\beta$ 's are the parameters to be estimated, $v$ and $\varsigma$ denote the error terms, and other variables are as defined before. Teenagers with higher BMI are likely to have a lower stock of education as aforementioned and, therefore, higher BMI is expected to reduce the likelihood of being in for managerial and professional occupations, or occupations requiring social interactions with customers or colleagues through the BMI effect (expected negative signs on $\delta^{B M I}$ and $\beta^{B M I}$ ) and the education effect (expected positive signs on $\delta^{\text {Educ }}$ and $\beta^{\text {Educ }}$ ). The hypothesized direction of the late teen BMI estimate remains the same under an alternative assumption that teenagers make occupation choice to maximize marginal productivity regardless of their stock of education.

After estimating equations (1), (3), (4), and (5), we can fill in values for equation (2) to estimate the full derivative of wages in the early career with respect to late teen BMI. We bootstrap the standard errors of all calculations based on equation (2).

We control for the time between the late teen BMI measurement and the early adult wage measurement across all the estimations to address the possibility that the effects of the late teen BMI may change with duration between the two measurements. We also control for the average age at which the late teen BMI is measured in all the estimation to account for potential 
variations in the effect of the late teen BMI at different ages between 16 and 20.

For all the estimations, we control for state-level labor market characteristics, including per capita average income, the Consumer Price Index, and the unemployment rate in the resident's area at the time of survey. State-level macroeconomic conditions control for time-varying macroeconomic shocks at the state level that could affect both individual health conditions and participation in the labor market (Ruhm, 2000; Ruhm, 2004).

Across all estimations, the late teen BMI measurement precedes the measurements for dependent variables as in Averett and Korenman (1996), Gortmaker et al. (1993), and Norton and Han (2008). This partly addresses the endogeneity problem of the late teen BMI. As aforementioned, controlling for the change in BMI between the late teenage years and the early thirties also partly accounts for the omitted variable bias because late teen BMI may be endogenous through its correlation with contemporaneous BMI which is correlated with labor market outcomes.

The previous literature on obesity and labor market outcomes has tried to control for the endogeneity of obesity using instrumental variables (Averett and Korenman, 1996; Conley and Glauber, 2005; Cawley, 2004; Behrman and Rosenzweig, 2001; Norton and Han, 2008) or fixed effect models (Averett and Korenman, 1996; Conley and Glauber, 2005; Cawley, 2004; Behrman and Rosenzweig, 2001, Han, Norton, and Stearns, 2009). However, we do not use those techniques. Some of those instruments in the previous studies, such as genetic information as in Norton and Han (2008) and mean BMI in the respondent's area of residence as in Morris (2006, 2007), are not available in the NLSY79. Other previously used instruments, including sibling's BMI, lagged self BMI, own child's BMI, are not clearly excluded in the wage regression, and therefore, we do not use them. In addition, risky behaviors, such as smoking, and 
drinking may proxy time preference, and controlling for these might mitigate the remaining endogeneity of late teen BMI as argued in Norton and Han (2008). However, those variables are not available in NLSY79.

Finally, we should note that we report a wage equation conditional on employment, and the results in the wage equation are all conditional on employment and do not generalize to all people in and out of the work force.. Many studies of hourly wages in the labor force estimate Heckman selection models to control for the unconditional effect on wages. However, Heckman selection models require identifying instruments, which should be correlated with the propensity to participate in the labor force, but not correlated with other explanatory variables in the wage equations. There are no plausible variables in the NLSY79 that satisfy these conditions. Models that have no such identifying variables rely solely on functional form for identification, and are notoriously unstable (Puhani, 2000; Dow and Norton, 2003).

\section{DATA}

\section{National Longitudinal Survey of Youth 1979 (NLSY79)}

Data drawn from the National Longitudinal Survey of Youth 1979 (NLSY79) are used for this study. The NLSY79 is a nationally-representative sample of 12,686 young men and women who were 14 to 22 years of age when first surveyed in 1979. Blacks, Hispanics, and economically disadvantaged non-black and non-Hispanics were over-sampled. The cohort was interviewed annually from 1979 through 1994 and biennially from 1996 onwards (U.S. Department of Labor, 2001). Four years of data $(1981,1982,1985$, and 1986) were pooled to create BMI in the late teenage years, and data from seven years $(1989,1990,1992,1993,1994,1996$, and 1998) were pooled to create the samples for this study. 
The final estimation sample is obtained after restricting our sample to those observations with BMI available in their late teenage years; labor market outcomes available in their early thirties (2,613 and 2,712 observations for women and men, respectively); and, excluding those in their early 30 s who were pregnant within a year from the time of the interview including pregnant at the time of the interview (2,196 women and 2,712 men are remained), or had missing data in other covariates in the estimation models (2,145 women and 2,052 men remained). Only observations for employed persons with occupation information were used for log hourly wages (1,514 women and 1,721 men from 2,145 women and 2,052 men).

\section{Dependent Variable: Wages, Education, and Occupation choices}

The four primary dependent variables in this study are wages, the stock of education, occupation choice based on the Census occupational classification and occupation choice with respect to occupations requiring social interactions as defined by the Dictionary of Occupational Titles (DOT). These four outcomes are defined at age 30 when possible (drawn from the 1989 through 1998 waves of the data); we filled any missing values with information until age 34 .

Wages are measured by the hourly rate of pay at the current job (CPS job). We deflate hourly wages to year 2000 dollars. For the stock of education, we use a continuous measure of the years of schooling completed.

We identify individuals out of the labor force separately from those who are unemployed but actively seeking employment. For the employed, we categorize individuals by their occupational characteristics. Employment and occupational choice have the following seven categories:

1) out of labor force; 
2) unemployed but actively seeking employment;

3) employed in service occupations;

4) employed in managerial or professional specialty occupations;

5) employed in sales occupations;

6) employed in administrative support or clerical occupations; and

7) employed in blue-collar occupations.

We adopt the aggregate occupational categories in the 1980 Census occupational classification system (U.S. Census Bureau, 1996). A blue-collar occupation is an aggregate category of the following census occupational categories: technicians and related support; farming, forestry, and fishing; precision production, craft, and repair; and operators, fabricators, and laborers.

Further, we categorize occupations by whether they require social interaction with customers or colleagues. The dependent variable is defined by the following four categories:

1) out of the labor force;

2) unemployed but actively seeking jobs;

3) employed in occupations requiring social interactions with customers or colleagues; and

4) employed in occupations not requiring social interactions with customers or colleagues. We use the Dictionary of Occupational Titles (DOT) to identify occupations requiring social interactions with customers or colleagues as in Hamermesh and Biddle (1994) and Han, Norton, Stearns (2009). The DOT was developed for standardizing occupational information by the U.S. Employment Service. In the DOT, blocks of jobs were assigned 9-digit occupational codes based on the nature of the work performed and the demands of such work activities upon the workers. Among the nine digits of each DOT code, the fifth digit reflects the relationship to people, which has nine categories: mentoring, negotiating, instructing, supervising, diverting, persuading, 
speaking-signaling, serving, and taking instructions-helping (Office of Administrative Law Judges Law Library, 1991). We include all but the last (taking instructions-helping) as an indicator that interpersonal interaction is an important aspect of an occupation, and thus, social interactions with customers or colleagues are required.

The summary statistics presented in Table 1 show that by one's early career, a man earns on average $\$ 14.55$ per hour at his current job, and a woman earns $\$ 10.80$ (all in 2000 dollars). The stock of education is similar between women and men, and the average years of schooling completed is approximately 13 years. Approximately $15 \%$ of women are out of labor force in their early thirties, whereas only $6 \%$ of men are out of labor force at the same age. The unemployment rate in the early $30 \mathrm{~s}$ is $5 \%$ for both genders. The majority of employed women in their early thirties have either managerial or professional specialties occupations (33\%) or administrative support or clerical occupations (25\%). For men, the most frequent aggregate occupational category in their early thirties is blue-collar occupations $(48 \%)$, followed by managerial or professional specialty occupations (27\%). The proportion of occupations requiring social interactions in the early career is almost even for both genders at $51 \%$.

Adult wages are slightly lower for those who were obese as teenagers versus those who were not for both women (\$9.60 versus $\$ 10.93)$ and men (\$13.12 versus $\$ 14.94)$. Obese teenagers of both genders eventually complete a half a year less of years of schooling compared to non-obese teenagers. Those who were obese teenagers are more likely to be out of labor force in their early thirties than non-obese teenagers (16\% versus $14 \%$ for women and $7 \%$ versus $6 \%$ for men). Fewer women, who were obese teenagers compared to non-obese teenagers, sort themselves out of managerial or professional specialty jobs ( $29 \%$ versus $33 \%)$, sales jobs ( $7 \%$ versus $10 \%)$, or blue-collar occupations (12\% versus $15 \%)$. For men, the distribution of 
occupation choice between obese and non-obese teenagers are similar to women except that obese male teenagers are more likely to sort into blue collar occupations than their non-obese counterparts (summary statistics by teenage obesity status are not shown).

\section{Explanatory Variable of Interest: BMI in the late teenage years}

The variable of primary interest is BMI in the late teenage years, defined as self-reported weight in kilograms divided by self-reported height in meters squared. In the NLSY79, height information was collected only three times, in 1981, 1982, and 1985, whereas a respondent's current weight was collected in every round of the survey used for this study. Because the respondents were between 20 and 28 years old in 1985, height in 1985 was used as the respondents' adult height following Cawley (2004) on the assumption that height typically stops changing by those ages.

To define BMI for individuals in their late teenage years, we took an average of a person's BMI at age between 16 and 20 years old. Average BMI in the late teenage years is 24.22 for women and 26.32 for men with a range of 16 to 58 (see Table 1).

\section{Other Control Variables}

Other covariates include change in BMI between the late teenage years and the early thirties, age, race, education level (years of schooling), marital status (married versus non-married), the number of children, the elapsed time from the latest pregnancy to the time of interview (indicators for being pregnant within 2 years, 4 years, and 6 years from the time of interview with not being pregnant within 6 years from the time of interview as the reference), highest grade completed by parents, height in meters, AFQT scores, and regional variables. We removed 
variation in age by restricting the outcome measured in the early 30s and BMI in the late teenage years. On average, BMI increased by 2 units for women and 1 unit for men between the late teenage years and their early 30s. Approximately sixty percent of the sample in the early 30 s was non-Hispanic White, and a quarter was non-Hispanic Black for both genders. More than one-half of the sample ( $61 \%$ of women and $56 \%$ of men) was married at the time of interview. The majority lived in urban areas (see Table 1).

The regional variables include the following variables: urban/rural status of the respondents' residential area, four regional areas in the US (South, Midwest, West, and Northeast as the reference), and unemployment rate in the residential area (larger than $12 \%$, between $9-12 \%$, between $6-9 \%$ with less than $6 \%$ as the reference). The unemployment rate in the residential area is at the metropolitan area level for the respondents residing in a metropolitan area. Otherwise, the unemployment rate is the state unemployment rate (not including Census metropolitan areas) in which the respondent resides, and this information was obtained from U.S. Department of Labor (2001). We also control for contextual macroeconomic conditions by including the following state-level covariates: total number of private businesses per 10,000 capita, per capita average income in $\$ 1,000$ deflated by yearly GDP by state, and the Consumer Price Index. The state level variables were obtained from the Census County and City Data Books by the U.S. Census Bureau (2000).

\section{RESULTS}

\section{Background evidence on the effects of BMI, education and occupation on wages.}

In Table 2, we begin by presenting empirical evidence on the underlying mechanisms in the relationship between late teen BMI and adult wages. In a regression of hourly wages in the early 
30s on late teen BMI and individual and regional characteristics with a constant term, a one-unit increase of BMI in the late teenage years is associated with a decrease in hourly wages of 0.92 percent for women. However, the extent of the wage penalty gradually decreases as we further control for the stock of education and occupation choice in the early 30s. The extent of the direct BMI wage penalty for women decreases to 0.80 and 0.83 percent, respectively, after controlling for the stock of education and occupation choice. Finally, the magnitude of the direct BMI wage penalty for women falls to 0.78 percent when we control for both the stock of education and occupation choice as shown in Model 4 (see left section in Table 2). Although the estimates are not statistically different across the four models, these results for women provide empirical support for our hypothesis that occupation choice and the stock of education may explain part of the observed lasting wage penalty for BMI in the late teenage years. It should be noted that the purpose of the estimation is to motivate further analyses that empirically quantify the extent of the indirect BMI wage penalty through education and occupation choice - not to test the statistical differences on the direct BMI wage penalty in the four regressions. No significant direct BMI wage penalty is found for men regardless of model specifications (see right section in Table 2). The control for the change in BMI throughout the 20s does not have a statistically significant association with hourly wages in the early thirties for either women or men.

There is a relatively large association between wages and the stock of education and occupation choice for both men and women. As shown in Model 4 in Table 2, having one additional year of schooling is associated with an increase in hourly wages by 2.4 and 3.6 percents for women and men, respectively. We also find that women and men, respectively, earn 14.0 and 17.1 percent higher hourly wages in managerial or professional specialty occupations compared to blue-collar occupations (the reference), whereas service occupations are associated 
with a 41.0 and 12.2 percent decrease in hourly wages for women and men, respectively (see Table 2).

\section{Stock of education in the early thirties}

Our study findings on the relationship between BMI in the late teenage years and the stock of education acquired by the early 30s show that higher BMI in the late teenage years is associated with a statistically significant reduction in years of schooling acquired by the early thirties for both women and men. As shown in Table 3, a one-unit increase in BMI in the late teenage years decreases the highest grade completed in the early thirties by 0.025 and 0.024 units for women and men, respectively.

\section{Employment and occupation choice in the early thirties}

As for the employment and occupation choice in the early 30 s, the results presented in Table 4 show that the effect of BMI in the late teenage years does not have a statistically significant effect on the long-term occupation choice based on the Census occupational classification in the early 30s overall. As an exception, we find that a one-unit increase in late teen BMI for women reduces the likelihood of being in a blue-collar occupation by 0.38 percentage points. The results also suggest that the lasting wage penalty in the early career for late teen BMI operates mainly through education. As expected, a year increase of the years of schooling completed raises the likelihood of having managerial or professional specialty occupations by 6.9 and 5.5 percentage points for women and men, respectively. On the other hand, for women, an additional year of education completed reduces the likelihood of having service occupations (by 1.8 percentage points), sales occupations (by 0.82 percentage points), and administrative support or clerical occupations (by 3.4 percentage points). Men with one additional year of education completed 
also are less likely to be out of the labor force and unemployed but actively seeking jobs by 1.2 and 1.3 percentage points, respectively, and also less likely to have blue-collar occupations by 6.7 percentage points and more likely to be in managerial or professional specialty occupations by 5.5 percentage points (see Table 4 ).

We also present multinomial results for occupation choice with respect to occupations requiring social interactions as defined by the Dictionary of Occupational Titles in Table 5. Late teen BMI has a negative effect on the probability of having occupations requiring social interactions for women to the extent that a one-unit increase of late teen BMI reduces the probability of being in occupations requiring social interactions by 0.43 percentage points. The association between the change in BMI and the likelihood of having an occupation requiring social interactions is not distinguishable from zero for either women or men. For men, the highest level of education is positively associated with having occupations not requiring social interactions by 2.5 percentage points (see Table 5).

\section{The extent of the direct and indirect BMI wage penalty}

Finally, in Table 6, we decompose the long-term wage penalty in the early career to quantify the direct effect and indirect effects of BMI in the late teen years that operate through education and occupation channels. For the direct BMI wage penalty, estimates in Table 2 show that a one-unit increase of late teen BMI decreases hourly wages by 0.78 percent for women after controlling for education and occupation choice. For men, however, there is no statistically significant direct BMI wage penalty conditional on education and occupation choice.

For women, in addition to the 0.78 percent $(90 \% \mathrm{CI}:[0.18,1.38])$ direct BMI wage penalty, we estimate an additional 0.18 percent reduction $(90 \% \mathrm{CI}$ : $[0.032,0.32])$ in wages due to a one- 
unit increase in late teen BMI resulting from the following indirect effects: 1) a 0.060 percent (90\% CI: $[0.014,0.11])$ decrease through the BMI effect on the stock of education; 2) a 0.050 percent $(90 \%$ CI: $[0.013,0.088])$ decrease due to reduced education which in turn affects occupation choice based on the Census occupational classification; 3) a 0.00098 percent decrease due to reduced education which in turn affects occupation choice with respect to occupations requiring social interactions based on the Dictionary of Occupational Titles (DOT); 4) a 0.045 percent decrease due to the BMI effect on occupation choice based on the Census occupational classification; and,5) a 0.0019 percent decrease due to the BMI effect on occupation choice with respect to occupations requiring social interactions as defined by DOT (see Table 6).

Whereas similar to the previous literature we do not find a direct BMI wage penalty for men, we do find a statistically significant indirect BMI wage penalty stemming from education and occupation choice operating through education. The total indirect effect of late teen BMI on hourly wages is estimated to reduce wages by 0.11 percent by adding up the estimates in the following pathways: 1) a 0.086 percent $(90 \% \mathrm{CI}:[0.020,0.15])$ decrease through the BMI effect on the stock of education; 2) a 0.024 percent (90\% CI: [0.0086, 0.041]) decrease due to reduced education which in turn affects occupation choice based on the Census occupational classification; 3) a 0.0011 percent decrease due to reduced education which in turn affects occupation choice with respect to occupations requiring social interactions based on the Dictionary of Occupational Titles (DOT); 4) a 0.0081 percent decrease due to the BMI effect on occupation choice based on the Census occupational classification; and,5) a 0.0057 percent increase due to the BMI effect on occupation choice with respect to occupations requiring social interactions as defined by DOT. Note, however, that whereas some of the components of the total indirect effect are statistically significant, the estimated total indirect effect for men does 
not achieve statistical significance (see Table 6).

Thus, we estimate a total 0.96 percent $(90 \%$ CI: $[0.29,1.62])$ decrease in wages for women resulting from each additional unit of late teen BMI where the indirect effect is 0.18 percent (90\% CI: $[0.032,0.32])$ which represents $19 \%(0.18$ out of 0.96$)$ of the estimated total BMI wage penalty. For men, we estimate a 0.11 percent decrease in wages indirectly for an additional unit of late teen BMI, albeit statistically not significant, which is originated from the negative relationship between late teen BMI and education.

\section{CONCLUSIONS}

We extend the existing literature by showing that the BMI wage gap in a given job stems in part from the indirect effect of BMI in the late teenage years on choices related to both education and occupation in early career. The indirect relationship between BMI and wages is driven by 1) the effect of late teen BMI on education which affects wages and 2) the effect of late teen BMI on education which, in turn, affects occupation choice which affects wages. The results show that higher late teen BMI leads to lower levels of accumulated education in the early thirties for both genders. However, late teen BMI is generally not found to be associated with occupation choice in the early thirties in either Census base or DOT base with a few exception for women. The effects of late teen BMI for women and men affects their choices for occupation in the early thirties mainly through investments in education.

The finding that late teenage women with a higher BMI have lower wages at age 30 deserves further discussion. In particular, what is the mechanism through which this may operate? We give three possible explanations. The first story is one of statistical discrimination. In this scenario, BMI is correlated with other permanent characteristics, such as the discount rate. 
Although BMI does not directly affect productivity, because it is observable, employers use it when setting initial wages. Over time, good workers reveal themselves and are paid more. On average though, many workers with high late teen BMI will be not good workers because of their discount rate and earn low wages throughout their career. However, we find that an interaction term between the years of schooling and a dummy variable indicator of obesity (BMI larger than 30 ) in an hourly wage regression is not statistically significant, which may imply that the statistical discrimination may not fully explain the late teen BMI wage penalty.

A second story is statistical. We essentially include both past and current BMI (actually past BMI and the change in BMI), which are positively correlated. When two correlated variables are included in a regression, the dominant one often is the one measured with less error. Past BMI may have lower measurement error if weight swings are wider in middle age, making a single BMI measurement a somewhat random snapshot of a volatile process driven by binges, diets, bouts of good intentions followed by relapses. If this story is correct, then late teen BMI may be a better measure of permanent body type due to lower measurement error.

Finally, fate may be revealed early. By age 18 many people may already be headed down their life path. Some have entered fine universities, others are pregnant or in jail. BMI may be correlated with these different paths. To the extent that future wages are predictable by age 18 , and socioeconomic status and education are related to late teen BMI, then this early fate view will be true.

The endogeneity of late teen BMI, our primary variable of interest, is partly controlled for in the estimation because it precedes the measurements for outcome variables. However, we acknowledge that our estimation results should be taken cautiously given that the models may not fully account for the potential endogeneity of BMI. Omitted variables related to both BMI 
and labor market outcomes will still cause endogeneity bias for late teen BMI, and unobserved individual-level heterogeneity, such as time preference is an example of such variables. If obese teenagers have a higher discount rate, estimated coefficients in the wage regression without encountering the endogeneity of late teen BMI would be biased downwards. Note that, however, we estimate a reduced form model, and accordingly, the endogeneity of other covariates such as the stock of education is less of concern in this paper.

We do not control for selection into the labor market in this study. We acknowledge that estimating hourly wages conditional on working may underestimate the BMI wage penalty if teenagers with higher BMI are likely to be out of labor force or unemployed. However, our estimates on occupational choice which includes both out of labor force and unemployed categories show statistically non-significant effects of late teen BMI on the likelihood of being out of labor force or unemployed. This may imply that the extent of bias of our wage estimates conditional on working may not be substantial.

We improve the previous literature by measuring occupations requiring social interactions. Note, however, that we do not differentiate skills requiring social interaction with colleagues from the skills requiring social interaction with customers. High BMI or obesity may cause a wage penalty in jobs requiring interactions with customers but may not have an effect on wages in jobs requiring interactions only with colleagues. If teenagers with high BMI could observe a wage penalty for their body mass, they might have more incentive to develop job skills to compensate the BMI effect.

Finally, we argue that a significant portion of the effect of BMI on labor market outcomes may occur prior to employment and, indeed, we show that previous studies that estimate the BMI wage penalty conditional on education and occupation underestimate the penalty for women. Our 
results for women show a total 0.96 percent decrease in wages resulting from each additional unit of late teen BMI with the indirect effects stemming from education and occupation choices making up $19 \%$ of the total estimated BMI wage penalty. We do not find a significant direct BMI wage penalty for men nor has one been found in the previous literature. However, we do find that each additional unit of late teen BMI for men decreases hourly wages via indirect pathways through education and occupation choice operating from education by 0.086 and 0.024 percent, respectively. These results suggest that in order to fully capture the relationship between BMI and labor market outcomes researchers need to account for the early part of the life-cycle when individuals make important choices such those related to human capital formation. 


\section{REFERENCES}

Averett S, Korenman S. "The economic reality of the beauty myth." Journal of Human Resources 31, 1996, 304-330.

Baum CL, Ford WF. "The wage effects of obesity: a longitudinal study.” Health Economics 13, 2004, 885-899.

Bhattacharya J, Bundorf MK. "The incidence of the health care costs of obesity". NBER Working Paper 11303, May 2005.

Carpenter CS. "The effects of employment protection for obese people." Industrial Relations 45(3), 2006, 393-415.

Cawley J. "An instrumental variables approach to measuring the effect of body weight on employment disability.” Health Services Research 35(5), 2000, 1159-1179.

Cawley J. "The impact of obesity on wages." Journal of Human Resources 39(2), 2004, 451-474.

Conley D, Glauber G. “Body mass and economic status”. NBER working paper 2005, \# 11343.

Everett M. "Let an overweight person call on your best customers? Fat chance.” Sales and Marketing Management 142, 1990, 66-70.

Garcia J, Quintana-Domeque C. "Obesity, Employment, and Wages in Europe. In: Kristian Bolin and John Cawley (eds.)." The Economics of Obesity, Advances in Health Economics and Health Services Research 17, 2007, 187-218.

Frieze IH, Josephine EO, and Good DC. "Perceived and actual discrimination in the salaries of male and female managers". J Appl Soc Psychology 20, 1990, 46-47.

Hamermesh DS, Biddle JE. "Beauty and the labor market." The American Journal or Economic Review 84(5), 1994, 1174-1194.

Han E, Norton EC, Stearns SS. "Weight and wages: Fat versus lean paychecks". Health 
Economics. Forthcoming 2008.

Harper B. "Beauty, structure and the labour market: A British cohort study." Oxford Bulletin of Economics and Statistics 62, 2000, 771-800.

Lakdawalla D, Philipson T. "Labor Supply and Weight." Journal of Human Resources 42(1), $2007,85-116$

Lundborg P et al. "Obesity and Occupational Attainment Among the 50+ of Europe. In: Kristian Bolin and John Cawley (eds.)". The Economics of Obesity, Advances in Health Economics and Health Services Research 17, 2007, 219-252.

Martel LF, Biller HB. "Statues and stigma: the biopsychosocial development of short males". Lexignton, Mass; Lexington Books. 1987.

Morris S. "The impact of obesity on employment." Labour Economics 14, 2007, 413-433.

Norton EC, Han E. "Using genetic information to identify causal effects of obesity." Health Economics 17, 2008, 1089-1104.

Puhl R, Brownell KD. "Bias, discrimination, and obesity." Obesity Research 9, 2001, 788-805.

Office of Administrative Law Judges Law Library. U.S. Department of Labor. Dictionary of Occupational Titles. Fourth edition, revised 1991. Accessed at March 11, 2005 from http://www.oalj.dol.gov/libdot.htm

Ogden CL, Carroll MD, Curtin LR et al. "Prevalence of overweight and obesity in the United States, 1999-2004.” JAMA 295(13), 2006, 1549-1555.

Pagan JA, Davila A. “Obesity, occupational attainment, and earnings.” Social Science Quarterly 78(3), 1997, 756-770.

Paraponaris A, Saliba B, Ventelou B. "Obesity, weight status and employability: empirical evidence from a French National Survey." Economics and Human Biology 3(2), 2005, 241 - 
258.

Persico N, Postlewaite A, and Silverman D. "The effect of adolescent experience on labor market outcomes: The case of height.” Journal of Political Economy. 112(5), 2004, 1019-1053.

Puhani PA. "The Heckman correction for sample selection and its critique". Journal of Economic Surveys 14(1), 2000, 53-68.

Ruhm CJ. “Are Recessions Good For Your Health?” Quarterly Journal of Economics 115 (2), $2000,617-650$

Ruhm CJ. "Maternal employment and adolescent development." NBER working paper 2004, \#10691.

Sabia JJ. "The effect of body weight on adolescent academic performance." Southern Economic Journal 73 (4), 2007, 871-900.

Sarlio-Lahteenkorva S, Lahelma E. "The association of body mass index with social and economic disadvantage in women and men." International Journal of Epidemiology 28(3), 1999, 445-449.

Tunceli K, Li KM, Williams LK. "Long-term effects of obesity on employment and work limitations among US adults, 1986 to 1999.” Obesity 14(9), 2006, 1637-1646.

U.S. Census Bureau. Current Population Survey, March 1996. Access at March 27, 2005 from http://www.census.gov/apsd/techdoc/cps/mar96/append_b.html

U.S. Census Bureau, U.S. Department of Commerce. County and City Data Book: 2000. Access at March 27, 2005 from http://www.census.gov/prod/www/ccdb.html.

U.S. Department of Labor. NLSY79 users' guide: A guide to the 1979-2000 National Longitudinal Survey of Youth. 2001. Accessed at March 11, 2005 from http://www.bls.gov/nls/79guide/2001/nls79g0.pdf. 
Table 1 . Weighted summary statistics

\begin{tabular}{|c|c|c|c|c|c|}
\hline \multirow[b]{2}{*}{ Variables } & \multicolumn{2}{|c|}{ Women } & \multicolumn{2}{|c|}{ Men } & \multirow[b]{2}{*}{ Range } \\
\hline & Mean & SD & Mean & $\mathrm{SD}$ & \\
\hline \multicolumn{6}{|l|}{ Dependent variables } \\
\hline Hourly wages & 10.80 & 9.12 & 14.55 & 12.78 & {$[1,660.69]$} \\
\hline Stock of education: highest grade completed & 13.46 & 2.35 & 13.13 & 2.51 & {$[3,20]$} \\
\hline \multicolumn{6}{|l|}{$\begin{array}{l}\text { Occupation choice based on Census } \\
\text { occupational code }\end{array}$} \\
\hline Out of labor force & 0.15 & 0.35 & 0.06 & 0.23 & {$[0,1]$} \\
\hline Unemployed & 0.05 & 0.22 & 0.05 & 0.21 & {$[0,1]$} \\
\hline Employed & 0.80 & 0.45 & 0.89 & 0.34 & {$[0,1]$} \\
\hline Service & 0.18 & 0.39 & 0.11 & 0.31 & {$[0,1]$} \\
\hline Managerial or professional specialties & 0.33 & 0.47 & 0.27 & 0.44 & {$[0,1]$} \\
\hline Sales & 0.09 & 0.29 & 0.08 & 0.27 & {$[0,1]$} \\
\hline Administrative support/clerical & 0.25 & 0.43 & 0.06 & 0.23 & {$[0,1]$} \\
\hline Blue-collar & 0.15 & 0.36 & 0.48 & 0.5 & {$[0,1]$} \\
\hline \multicolumn{6}{|l|}{$\begin{array}{l}\text { Occupation choice based on } \\
\text { the Dictionary of Occupation Titles }\end{array}$} \\
\hline \multicolumn{6}{|l|}{ Independent variable of interest } \\
\hline BMI in the teenage years between age 16 and 20 & 24.22 & 4.32 & 26.32 & 4.38 & {$[15.62,57.66]$} \\
\hline \multicolumn{6}{|l|}{ Race } \\
\hline White & 0.56 & 0.49 & 0.57 & 0.49 & {$[0,1]$} \\
\hline Black & 0.26 & 0.44 & 0.25 & 0.43 & {$[0,1]$} \\
\hline Hispanic & 0.18 & 0.38 & 0.18 & 0.38 & {$[0,1]$} \\
\hline Highest grade completed by mother & 10.98 & 3.15 & 11.11 & 3.15 & {$[0,20]$} \\
\hline Highest grade completed by father & 10.98 & 3.88 & 11.17 & 3.84 & {$[0,20]$} \\
\hline Married & 0.61 & 0.49 & 0.56 & 0.50 & {$[0,1]$} \\
\hline Number of children & 1.48 & 1.10 & 1.01 & 1.11 & {$[0,3]$} \\
\hline AFQT scores & 41.10 & 27.23 & 41.28 & 29.39 & {$[1,99]$} \\
\hline Height (meters) & 1.63 & 0.07 & 1.78 & 0.08 & {$[1.22,1.98]$} \\
\hline $\begin{array}{l}\text { BMI in the early thirties - BMI in the late teenage } \\
\text { year }\end{array}$ & 2.27 & 4.77 & 0.97 & 4.27 & {$[-16.67,23.84]$} \\
\hline \multicolumn{6}{|l|}{ Pregnancy } \\
\hline $\begin{array}{l}\text { Being pregnant within } 2 \text { years from the time of } \\
\text { interview }\end{array}$ & 0.23 & 0.42 & N/A & $\mathrm{N} / \mathrm{A}$ & {$[0,1]$} \\
\hline $\begin{array}{l}\text { Being pregnant between } 2-4 \text { years from the time } \\
\text { of interview }\end{array}$ & 0.29 & 0.45 & N/A & N/A & {$[0,1]$} \\
\hline $\begin{array}{l}\text { Being pregnant between } 4-6 \text { years from the time } \\
\text { of interview }\end{array}$ & 0.35 & 0.48 & N/A & N/A & {$[0,1]$} \\
\hline $\begin{array}{l}\text { Not being pregnant within } 6 \text { years from the time } \\
\text { of interview }\end{array}$ & 0.13 & 0.38 & N/A & N/A & {$[0,1]$} \\
\hline Mean age for the late teen BMI observation & 18.66 & 0.6 & 18.64 & 0.6 & {$[17,19.5]$} \\
\hline Time between the teen BMI observation and the & 11.8 & 0.99 & 11.71 & 0.85 & {$[10.5,16.5]$} \\
\hline
\end{tabular}


Regional variables

Unemployment rate: $<6 \%$

Unemployment rate: $6-9 \%$

$\begin{array}{llll}0.40 & 0.49 & 0.40 & 0.49\end{array}$

$[0,1]$

Unemployment rate: $9-12 \%$

$\begin{array}{llll}0.41 & 0.49 & 0.41 & 0.49\end{array}$

$[0,1]$

Unemployment rate: $>12 \%$

$\begin{array}{llll}0.10 & 0.30 & 0.11 & 0.32\end{array}$

Number of private businesses per 10,000 at

$\begin{array}{llll}0.09 & 0.28 & 0.08 & 0.27\end{array}$

$\begin{array}{llll}250.59 & 22.46 & 251.17 & 23.29\end{array}$

$[0,1]$

the state-level

State per capita average yearly income in

$\$ 1,000$

The Consumer Price Index

$\begin{array}{llll}21.90 & 2.57 & 21.99 & 2.51\end{array}$

$[205.35,362.10]$

West

North-central

$\begin{array}{llll}0.19 & 0.39 & 0.20 & 0.40\end{array}$

0.06

$[15.42,30.12]$

South

$\begin{array}{llll}0.25 & 0.43 & 0.26 & 0.44\end{array}$

$[1.39,1.58]$

Urban

0.40

0.49

0.36

0.48

$[0,1]$

0.80

0.40

0.81

0.40

$[0,1]$

$[0,1]$

$[0,1]$

$2,145 \quad 2,052$ 
Table 2. OLS estimation results of log hourly wages in the early career on BMI in the late teenage years, the stock of education, and occupation choice in early career

\begin{tabular}{|c|c|c|c|c|c|c|c|c|}
\hline \multirow[t]{2}{*}{ Selected point estimates } & \multicolumn{4}{|c|}{ Women $(N=1,514)$} & \multicolumn{4}{|c|}{$\operatorname{Men}(N=1,721)$} \\
\hline & Model 1 & Model 2 & Model 3 & Model 4 & Model 1 & Model 2 & Model 3 & Model 4 \\
\hline \multirow[t]{2}{*}{ Late teen BMI } & $-0.0092 * *$ & $-0.0080 *$ & $-0.0083 * *$ & $-0.0078 *$ & 0.0007 & 0.0025 & 0.0017 & 0.0028 \\
\hline & $(0.0043)$ & $(0.0041)$ & $(0.0040)$ & $(0.0040)$ & $(0.0035)$ & $(0.0034)$ & $(0.0034)$ & $(0.0034)$ \\
\hline \multirow{2}{*}{$\begin{array}{l}\text { Adult BMI - } \\
\text { Late teen BMI }\end{array}$} & -0.005 & -0.0037 & -0.0037 & -0.0034 & 0.0021 & 0.0039 & 0.0024 & 0.0036 \\
\hline & $(0.0036)$ & $(0.0035)$ & $(0.0034)$ & $(0.0034)$ & $(0.0038)$ & $(0.0038)$ & $(0.0037)$ & $(0.0037)$ \\
\hline \multirow[t]{2}{*}{ Highest grade completed } & & $0.0503 * * *$ & & $0.0237 * *$ & & $0.0510 * * *$ & & $0.0364 * * *$ \\
\hline & & $(0.0100)$ & & $(0.0107)$ & & $(0.0086)$ & & $(0.0092)$ \\
\hline \multirow{2}{*}{$\begin{array}{l}\text { Managerial or professional } \\
\text { specialties }\end{array}$} & & & $0.1709 * * *$ & $0.1395 * * *$ & & & $0.2323 * * *$ & $0.1707 * * *$ \\
\hline & & & $(0.0477)$ & $(0.0501)$ & & & $(0.0390)$ & $(0.0422)$ \\
\hline \multirow[t]{2}{*}{ Service } & & & $-0.4155^{* * *}$ & $-0.4095 * * *$ & & & $-0.1107 * * *$ & $-0.1219 * * *$ \\
\hline & & & $(0.0594)$ & $(0.0591)$ & & & $(0.0420)$ & $(0.0411)$ \\
\hline \multirow[t]{2}{*}{ Sales } & & & -0.1047 & -0.1007 & & & $0.1050 *$ & 0.0877 \\
\hline & & & $(0.0675)$ & $(0.0673)$ & & & $(0.0609)$ & $(0.0606)$ \\
\hline \multirow{2}{*}{$\begin{array}{l}\text { Administrative } \\
\text { support/clerical }\end{array}$} & & & -0.0694 & -0.0617 & & & -0.0108 & -0.0335 \\
\hline & & & $(0.0484)$ & $(0.0475)$ & & & $(0.0561)$ & $(0.0571)$ \\
\hline \multirow{2}{*}{$\begin{array}{l}\text { Occupation requiring } \\
\text { social interaction }\end{array}$} & & & 0.0446 & 0.0445 & & & 0.0226 & 0.0188 \\
\hline & & & $(0.0358)$ & $(0.0357)$ & & & $(0.0317)$ & $(0.0316)$ \\
\hline
\end{tabular}

Note:

a. All models control for the following covariates: age, race, marital status (married versus nonmarried), the elapsed time from the latest pregnancy to the time of interview (indicators for being pregnant within 2 years, 4 years, and 6 years from the time of interview with not being pregnant within 6 years from the time of interview as the reference), highest grade completed by parents, height in meters, AFQT scores, and regional variables, which include urban/rural status of the respondents' residential area, four regional areas in the US (South, Midwest, West, and Northeast as the reference), unemployment rate in the residential unit (larger than $12 \%$, between $9-12 \%$, between $6-9 \%$ with less than $6 \%$ as the reference), total number of private businesses per 10,000 capita at the state level, per capita average income in $\$ 1,000$ deflated by yearly GDP by state, and the Consumer Price Index.

b. Standard errors for the marginal effects are in the parentheses.

c. Unit of observation is person.

d. $* p<0.1, * * p<0.05, * * * p<0.01$ 
Table 3. The marginal effect of the BMI at the late teenage years on the years of schooling completed in early career in OLS

\begin{tabular}{lcc}
\hline $\begin{array}{l}\text { Dependent variable: Years of schooling } \\
\text { completed }\end{array}$ & Women & Men \\
\hline Late teen BMI & $-0.0254^{* *}$ & $-0.0236^{* *}$ \\
& $(0.0123)$ & $(0.0108)$ \\
\hline$N$ & 2,145 & 2,052 \\
\hline
\end{tabular}

Notes from Table 2 all apply. 
Table 4. The marginal effect of BMI at the late teenage years on occupation choice in early career in a multinomial logit model Selected point estimates

Outcome variable: employment and occupational choice categories

\begin{tabular}{|c|c|c|c|c|c|c|c|}
\hline & & & & & & & \\
\hline & $\begin{array}{c}\text { Out of } \\
\text { labor force }\end{array}$ & $\begin{array}{l}\text { Unemployed } \\
\text { but in the } \\
\text { labor force }\end{array}$ & Service & $\begin{array}{c}\text { Managerial / } \\
\text { professional } \\
\text { specialty }\end{array}$ & Sales & $\begin{array}{c}\text { Administrative } \\
\text { support / } \\
\text { clerical }\end{array}$ & Blue-collar \\
\hline \multicolumn{8}{|l|}{ Women $(N=2,145)$} \\
\hline \multirow[t]{2}{*}{ Late teen BMI } & 0.0000 & 0.0003 & 0.0017 & 0.0019 & 0.0010 & -0.0010 & $-0.0038^{* *}$ \\
\hline & $(0.0023)$ & $(0.0012)$ & $(0.0022)$ & $(0.0022$ & 0.0016 & 0.0023 & 0.0017 \\
\hline \multirow[t]{2}{*}{ Adult BMI - Late teen BMI } & $0.0035^{*}$ & -0.0012 & -0.0017 & $-0.0040^{*}$ & -0.0025 & $0.0042 *$ & 0.0017 \\
\hline & $(0.0018)$ & $(0.0011)$ & $(0.0016)$ & $(0.0021$ & 0.0016 & 0.0024 & 0.0015 \\
\hline Years of schooling completed & $\begin{array}{c}-0.0002 \\
(0.0052)\end{array}$ & $\begin{array}{l}-0.0033 \\
(0.0026)\end{array}$ & $\begin{array}{c}-0.0180^{* * *} \\
(0.0048)\end{array}$ & $\begin{array}{c}0.0685^{* * *} \\
0.0050\end{array}$ & $\begin{array}{c}-0.0082 * * \\
0.0035\end{array}$ & $\begin{array}{c}-0.0340 \text { *** } \\
0.0049\end{array}$ & $\begin{array}{c}-0.0049 \\
0.0043\end{array}$ \\
\hline \multicolumn{8}{|l|}{$\operatorname{Men}(N=2,052)$} \\
\hline Late teen BMI & $\begin{array}{c}0.0013 \\
(0.0013)\end{array}$ & $\begin{array}{l}-0.0020 \\
(0.0015)\end{array}$ & $\begin{array}{l}-0.0005 \\
(0.0021)\end{array}$ & $\begin{array}{l}0.0000 \\
0.0021\end{array}$ & $\begin{array}{c}-0.0017 \\
0.0016\end{array}$ & $\begin{array}{c}-0.0004 \\
0.0012\end{array}$ & $\begin{array}{l}0.0033 \\
0.0028\end{array}$ \\
\hline Adult BMI - Late teen BMI & $\begin{array}{l}-0.0026^{*} \\
(0.0015)\end{array}$ & $\begin{array}{c}0.0027 * * \\
(0.0012)\end{array}$ & $\begin{array}{c}-0.0018 \\
(0.0018)\end{array}$ & $\begin{array}{l}0.0011 \\
0.0022\end{array}$ & $\begin{array}{l}0.0014 \\
0.0018\end{array}$ & $\begin{array}{l}0.0011 \\
0.0015\end{array}$ & $\begin{array}{c}-0.0018 \\
0.0029\end{array}$ \\
\hline Years of schooling completed & $\begin{array}{l}-0.0123^{*} \\
(0.0063)\end{array}$ & $\begin{array}{c}-0.0132^{* *} \\
(0.0057)\end{array}$ & $\begin{array}{l}-0.0058 \\
(0.0083)\end{array}$ & $\begin{array}{c}0.0552 * * * \\
0.0099\end{array}$ & $\begin{array}{c}-0.0080 \\
0.0058\end{array}$ & $\begin{array}{c}-0.0014 \\
0.0057\end{array}$ & $\begin{array}{c}-0.0667 * * * \\
0.0116\end{array}$ \\
\hline
\end{tabular}

Notes from Table 2 all apply. 
Table 5. The marginal effect of BMI at the late teen years on occupation choice in the early career by the requirement of social interactions with customers or colleagues in a multinomial logit model

\begin{tabular}{|c|c|c|c|c|}
\hline \multirow[t]{2}{*}{ Independent variable of interest } & \multicolumn{4}{|c|}{$\begin{array}{c}\text { Outcome variable: employment and occupational choice } \\
\text { categories }\end{array}$} \\
\hline & $\begin{array}{l}\text { Out of } \\
\text { labor force }\end{array}$ & $\begin{array}{l}\text { Unemploye } \\
\mathrm{d} \text { but in the } \\
\text { labor force }\end{array}$ & $\begin{array}{l}\text { Employed } \\
\quad \text { at } \\
\text { Occupation } \\
\text { s requiring } \\
\quad \text { social } \\
\text { interactions }\end{array}$ & $\begin{array}{l}\text { Employed at } \\
\text { Occupations } \\
\text { not requiring } \\
\quad \text { social } \\
\text { interactions }\end{array}$ \\
\hline \multicolumn{5}{|l|}{ Women $(N=2,145)$} \\
\hline Late teen BMI & $\begin{array}{l}-0.0003 \\
(0.0021)\end{array}$ & $\begin{array}{c}0.0003 \\
(0.0012)\end{array}$ & $\begin{array}{l}-0.0043^{*} \\
(0.0025)\end{array}$ & $\begin{array}{c}0.0043 \\
(0.0031)\end{array}$ \\
\hline Adult BMI - Late teen BMI & $\begin{array}{c}0.0036^{* *} \\
(0.0018)\end{array}$ & $\begin{array}{l}-0.0012 \\
(0.0011)\end{array}$ & $\begin{array}{l}-0.0013 \\
(0.0024)\end{array}$ & $\begin{array}{l}-0.0011 \\
(0.0024)\end{array}$ \\
\hline Highest grade completed & $\begin{array}{l}-0.0039 \\
(0.0050)\end{array}$ & $\begin{array}{c}-0.0046 * \\
(0.0025)\end{array}$ & $\begin{array}{l}-0.0002 \\
(0.0062)\end{array}$ & $\begin{array}{c}0.0087 \\
(0.0060)\end{array}$ \\
\hline \multicolumn{5}{|l|}{$\operatorname{Men}(N=2,052)$} \\
\hline Late teen BMI & $\begin{array}{c}0.0014 \\
(0.0015)\end{array}$ & $\begin{array}{l}-0.0019 \\
(0.0014)\end{array}$ & $\begin{array}{c}0.0030 \\
(0.0031)\end{array}$ & $\begin{array}{l}-0.0026 \\
(0.0032)\end{array}$ \\
\hline Adult BMI - Late teen BMI & $\begin{array}{l}-0.0025 \\
(0.0016)\end{array}$ & $\begin{array}{c}0.0027 * * \\
(0.0012)\end{array}$ & $\begin{array}{l}-0.0006 \\
(0.0030)\end{array}$ & $\begin{array}{c}0.0004 \\
(0.0030)\end{array}$ \\
\hline Highest grade completed & $\begin{array}{c}-0.0091 * * * \\
(0.0029) \\
\end{array}$ & $\begin{array}{c}-0.0094 * * * \\
(0.0027)\end{array}$ & $\begin{array}{l}-0.0070 \\
(0.0064)\end{array}$ & $\begin{array}{c}0.0254 * * * \\
(0.0059) \\
\end{array}$ \\
\hline
\end{tabular}

Notes from Table 2 all apply. 
Table 6. Decomposition of the long-term wage penalty in early career for BMI in the late teen years: quantification of the direct effect and indirect effects operating through education and occupation channels.

\begin{tabular}{lcc}
\hline Indirect and direct BMI wage penalty & Women & Men \\
\hline $\begin{array}{l}\text { Channels of the indirect effects } \\
\text { Education }\end{array}$ & $-0.00060^{* *}$ & $-0.00086^{* *}$ \\
& $(0.00028)$ & $(0.00040)$ \\
& -0.00045 & -0.000081 \\
& $(0.0012)$ & $(0.00060)$ \\
Occupation choice: measured as the Census & & \\
occupational categories & -0.00019 & 0.000057 \\
Occupational characteristics of requiring social & $(0.00031)$ & $(0.00015)$ \\
interactions with customers or colleagues & $-0.00050^{* *}$ & $-0.00024^{* *}$ \\
& $(0.00023)$ & $(0.000097)$ \\
Education through occupation choice measured as & & \\
the Census occupational categories & -0.0000098 & -0.000011 \\
& $(0.000015)$ & $(0.000022)$ \\
Education through Occupational characteristics of \\
requiring social interactions with customers or & & \\
colleagues & $-0.0018^{* *}$ & -0.0011 \\
& $(0.00087)$ & $(0.00086)$ \\
Sum of indirect effects & $-0.0078^{* *}$ & 0.0028 \\
& $(0.0036)$ & $(0.0037)$ \\
Direct effect & $-0.0096^{* *}$ & 0.0016 \\
& $(0.0040)$ & $(0.0037)$ \\
\hline
\end{tabular}

Note:

a. Standard errors, calculated from bootstrapping, are in the parentheses.

b. $* p<0.1, * * p<0.05, * * * p<0.01$ 